\title{
FORMATION OF CUBE TEXTURE IN NOMINALLY PURE ALUMINUM WITH FINE PARTICLE DISPERSION
}

\author{
S. SAIMOTO, JIAN LI, G. LANGELAAN, B. J. DIAK and J. SHIMIZU ${ }^{1}$ \\ Dept. of Materials and Metallurgical Eng., Queen's University, Kingston, Ontario, \\ Canada K7L $3 N 6$
}

(Received 8 January 1995)

\begin{abstract}
An X-ray method to observe in-situ cube grain growth during recrystallization has been devised using a hot stage to measure the growth kinetics. Complementary studies, using electron channelling contrast, electron backscattered pattern and X-ray textural analysis, revealed that specific thermal-mechanical history can precipitate out $\mathrm{Fe}$ solutes such that the matrix is sufficiently pure to undergo continuous recrystallization even though a fine distribution of precipitate are initially formed. These precipitates control via Zener drag the grain size upon complete recrystallization. On the other hand, 2 to $3 \mathrm{ppm}$ (atomic) of $\mathrm{Fe}$ is sufficient to impose discontinuous recrystallization where the final grain size is controlled by grain impingement. The apparent activation energies for grain growth during recrystallization can be separated into two categories, the one for continuous recrystallization is smaller than that for $\mathrm{Fe}$ diffusion in $\mathrm{Al}$ and the one for discontinuous process is larger. Examination of volume fraction for each textural component reveals that during recrystallization the amount of cube texture growth correlates best with the decrease of the brass component. The increase in volume fraction of cube texture during recrystallization corresponds very well to the hot stage observations of cube grain growth.
\end{abstract}

KEY WORDS: Cube texture, rolling, recrystallization, X-ray, EBSP, Zener drag.

\section{INTRODUCTION}

The contributions of $\mathrm{Hsun} \mathrm{Hu}$ to the field of texture and recrystallization in research and practice can only be partially recognized by allusions to his papers by all the authors in this commemorative volume. Hu's (1952) early pole figure determinations are found in standard texts of X-ray methods (Cullity, 1978) and the caveat that the surface texture can differ from that of the mid-plane is attributed to his early study. The recent text by Humphreys and Hatherly (1995) points out that many contradicting conclusions can be drawn from specific experiments, where the role of the alloy chemistry is not determined or determinable. In the present paper we wish to examine a new quantitative technique to reveal the role of composition and the deformed microstructure on recrystallization and cube grain growth. This important topic was initially reviewed by $\mathrm{Hu}$ (1967) in the first ICOTOM meeting.

\footnotetext{
'Toyo Aluminum K.K. R\&D Laboratory, 4-1 Aioi-Cho, Yao-Sei, Osaka, 581, Japan.
} 


\section{Design of Experiment}

This preliminary report is based on an unique, method to monitor in-situ cube grain growth while the specimen is annealed in a programmable hot stage mounted in a Huber diffractometer incorporating the Euler cradle with a gap. The precision of this system is excellent, such that residual stresses during temperature cycling can be determined (Clarke, Saimoto and Ho, 1994; Clarke and Saimoto, 1995). The dynamic data was supplemented by prior and post observations using orientation distribution function (ODF) texture analysis from X-rays, electron channelling contrast (ECC) in the scanning electron microscope (SEM) and by electron back-scattered pattern analysis (EBSP). These latter techniques and their usefulness in recrystallization studies have been recently discussed by Woldt and Juul-Jensen (1995). Moreover, a novel technique to determine the solvus for Al-Cr (Diak, Whitehead and Saimoto, 1994) was used to determine the amount of $\mathrm{Fe}$ in solution for the starting material. This measurement permits an estimate of the volume fraction $\left(f_{v}\right)$ of the intermetallic precipitates present and the values are found in Table 1. For the current purpose, $\mathrm{Al}_{3} \mathrm{Fe}$ is assumed although $\mathrm{Al}_{6} \mathrm{Fe}$ is a possibility. Furthermore, an approximate precipitate size can be determined from the critical Zener drag conditions for a given grain size after complete recrystallization.

For the study of recrystallization of these sheets, the role of tool contact on rolled sheet and its effect on texture evolution is important ( $\mathrm{Li}$, Saimoto and Sang, 1994). However, it is impractical to measure the reactions at just the mid-plane since the resultant cube texture is highly dependent upon regions nearer to the surface (Saimoto, 1986). To quantitatively embody the role of the variation in through thickness texture, a phenomenon first appreciated by Hsun $\mathrm{Hu}$ (1952), pole figures were analyzed using monoclinic symmetry, as described earlier (Saimoto et al., 1993). This method retains during the ODF analysis the asymmetry of the X-ray intensities attributable to the unequal occurrence of $\mathrm{S}_{1}, \mathrm{~S}_{2}$ and $\mathrm{Cu}_{1}, \mathrm{Cu}_{2}$ texture components. The following results

Table 1 Measured solute content, grain size and apparent activation energies for sheets with two different thermal histories.

\begin{tabular}{lcc}
\hline Quantity $\backslash$ Sample & $A$ & $B$ \\
\hline Estimated Fe in Solution (at. \%) & $8.31 \times 10^{-5}$ & $2.26 \times 10^{-4}$ \\
Estimated $\mathrm{Al}_{3} \mathrm{Fe}$ Vol. Fraction (\%) & $2.76 \times 10^{-3}$ & $2.19 \times 10^{-3}$ \\
Mean Grain Diameter in & 123 & 376 \\
Annealed $8 \mathrm{~mm}$ Plate $(\mu \mathrm{m})$ & $\left(\right.$ at $\left.335^{\circ} \mathrm{C}\right)$ & $\left(\right.$ at $\left.400^{\circ} \mathrm{C}\right)$ \\
$\begin{array}{l}\text { Mean Grain Diameter in } 350 \mu \mathrm{m} \\
\text { Sheet after } 320^{\circ} \mathrm{C}(\mu \mathrm{m})\end{array}$ & 54 & 59 \\
$\begin{array}{l}\text { Mean Grain Diameter in } 350 \mu \mathrm{m} \\
\text { Sheet after } 335^{\circ} \mathrm{C}(\mu \mathrm{m})\end{array}$ & & - \\
$\begin{array}{l}\text { Mean Grain Diameter in } 350 \mu \mathrm{m} \\
\text { Sheet after } 380^{\circ} \mathrm{C}(\mu \mathrm{m})\end{array}$ & 65 & 107 \\
$\begin{array}{l}\text { Apparent Mean Activation } \\
\text { Energy for Cube Grain Growth } \\
\text { during Primary Recrystallization }\end{array}$ & 82 & \\
\hline
\end{tabular}


clearly illustrate that the role of the matrix chemistry and that of the dispersed particle size and distribution can be separated. However, the driving force for grain boundary migration can differ dramatically depending on the effect of solutes on stabilizing the dislocated microstructure.

\section{EXPERIMENTAL PROCEDURES}

A nominally pure aluminum ingot $435 \mathrm{~mm}$ thick was prepared with impurity composition in $\mathrm{ppm}(\mathrm{wt})$ of $19 \mathrm{Si}-16 \mathrm{Fe}-24 \mathrm{Cu}-3 \mathrm{Mn}-2 \mathrm{Cr}-13 \mathrm{Zn}$. The outer $10 \mathrm{~mm}$ surface layer was scalped from each side of the ingot and then it was homogenized at $610^{\circ} \mathrm{C}$ for 10 hours. The ingot was then hot rolled down to $8 \mathrm{~mm}$ thickness in the temperature range of 863 to $523 \mathrm{~K}$ ( 590 to $\left.250^{\circ} \mathrm{C}\right)$. The $8 \mathrm{~mm}$ thick plate was divided into two parts, $\mathbf{A}$ and $\mathbf{B}$, and each given a different annealing schedule. Annealing of sample $\mathbf{A}$ consisted of 10 hours at $608 \mathrm{~K}\left(335^{\circ} \mathrm{C}\right)$, whereas annealing of sample B consisted of 1 hour at $608\left(335^{\circ} \mathrm{C}\right)$ followed by 1 hour at $673 \mathrm{~K}\left(400^{\circ} \mathrm{C}\right)$. The procedure described by Diak et al. (1994) was used to measure the solute Fe content (Diak and Saimoto) which is listed in Table 1. As expected, sample $\mathbf{A}$ has considerable less amount of $\mathrm{Fe}$ in solution than $\mathbf{B}$. This difference is reflected in the recrystallized grain size measurements following the post hot-roll treatment (Table 1). Samples A and B were then both cold rolled from $8 \mathrm{~mm}$ down to a final thickness of $0.35 \mathrm{~mm}$. Pieces approximately $22 \times 14 \mathrm{~mm}^{2}$ were cut from continuous strips parallel to the rolling direction such that the surface embossing effects were as identical as possible from specimen to specimen. To permit ECC observation and to remove the major surface damage ( $\mathrm{Li}$, Saimoto and Sang, 1994), 3 to $4 \mu \mathrm{m}$ was electropolished from the surface using a dilute perchloric acid-alcohol solution at about $263 \mathrm{~K}\left(-10^{\circ} \mathrm{C}\right)$. After subsequent anneals in air in the in-situ hot stage, SEM ECC image resolution was not detectably different. This condition is expected from the fact that aluminum oxide coatings thicken by only a factor of 2 upon heating to temperatures of $613 \mathrm{~K}\left(340^{\circ} \mathrm{C}\right)$ (Olefjord and Karlson, 1986).

The JEOL 840 SEM was used for all the ECC observation with a working distance of $10 \mathrm{~mm}$ and an acceleration voltage of $10 \mathrm{kV}$. The EBSP were obtained using a LINK camera and the patterns were analyzed using the software purchased from NH. Schmidt (Randers, Denmark). The texture and hot-stage goniometer utilized an Euler cradle with a gap and its performance is described by Clarke and co-workers (1994, 1995). Four incomplete $\mathrm{X}$-ray pole figures were taken using $\mathrm{Cr}$ radiation and the ODF with monoclinic symmetry was analyzed using the modified Van Houtte software (Saimoto et al., 1993). All the anneals were performed in-situ in the programmable hot stage such that the rates of heating and isothermal holding times were recorded simultaneously with the (111) or (200) peak scans, which took about 40-50 seconds. For the as-received cold-rolled sheets, the primary beam cross-section at the specimen was about $1 \times 4 \mathrm{~mm}^{2}$. Using this spot size and the (111) reflection, the maximum intensities were located using the $\pm \chi$ angle drive of the diffractometer. After heating to beyond $523 \mathrm{~K}\left(250^{\circ} \mathrm{C}\right)$ where some cube grains were detectable, the width of the primary beam was increased so that an area $4 \times 8 \mathrm{~mm}^{2}$ was irradiated for the (200) reflection. Since the $\chi$ angle is near zero for maximum intensity, this widening of the slit improved the counting statistics of the partially recrystallized structure and the large grains which resulted after grain growth. All the quoted kinetic studies were measured in this way except for Figure 1, which used the narrower slit. 


\section{RESULTS}

To initially examine the practicality of studying the kinetics of cube texture growth in the hot stage, the as-rolled sheets without electropolishing were annealed with heating programs shown in Figure 1. The dramatic difference between samples $\mathbf{A}$ and $\mathbf{B}$ is obvious. The A sample appear to depict Zener drag characteristics, whereas B samples show grain impingement. Electropolishing was essential to remove the damaged layer and permit ECC observation, but an unexpected feature manifested itself. The position of maximum cube texture appears to vary in both $\chi$ and $\phi$ (rotation about specimen normal) angles. In fact some peaks decrease with annealing time, whereas others increase. Thus some searching is necessary to locate the stable orientations which grow in order to measure the growth kinetics.

The measured solute content and grain sizes of the starting $8 \mathrm{~mm}$ plate are given in Table 1. The larger grain size for the $B$ samples is in keeping with the lower $f_{v}$ and expected larger particle size for the $673 \mathrm{~K}\left(400^{\circ} \mathrm{C}\right)$ stabilized plate. Sections of the $8 \mathrm{~mm} \mathrm{~A}$ plates were electropolished and annealed in stages of $1 \mathrm{hr}$. at 608,633 ,

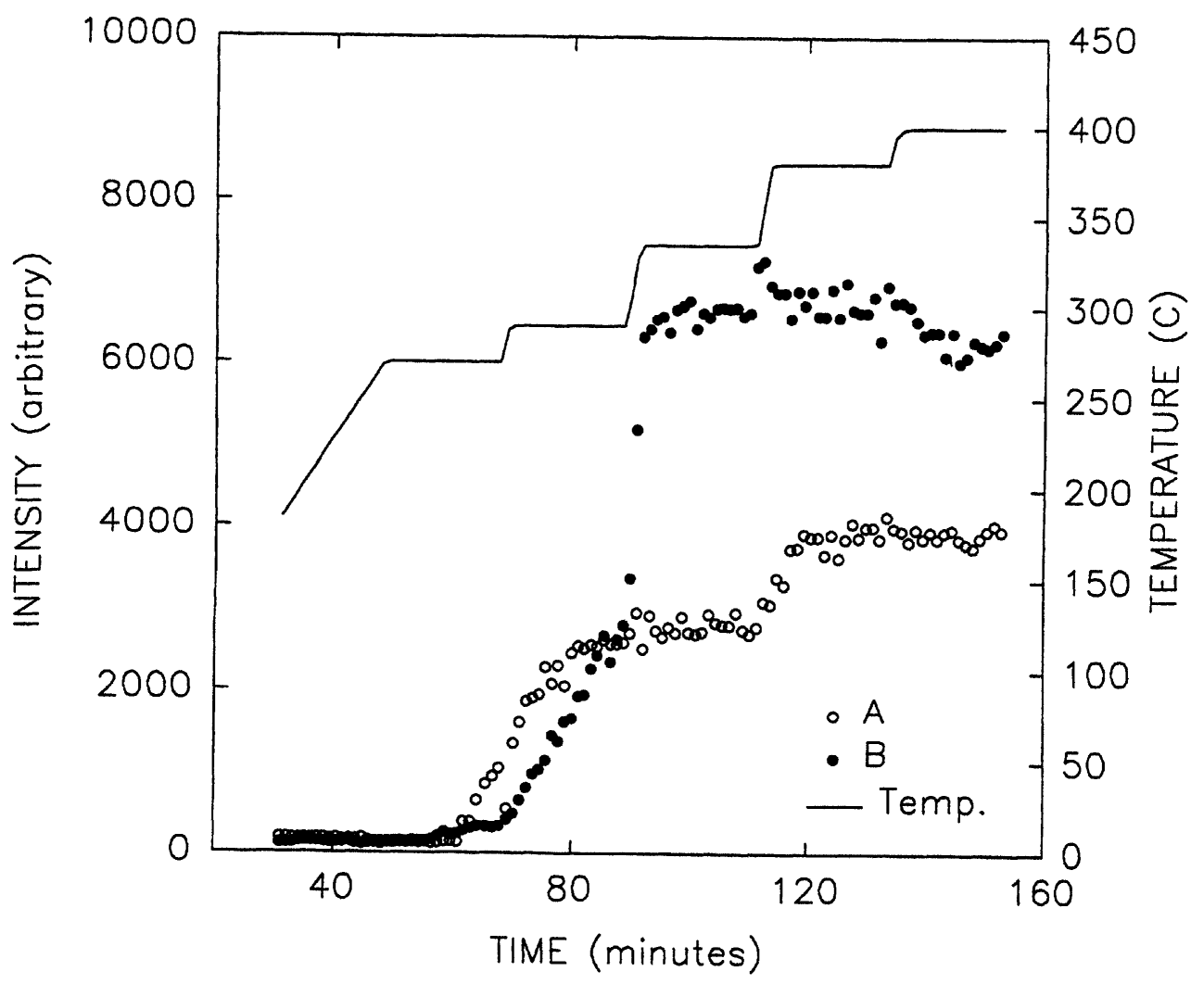

Figure 1 Comparison of (200) intensity for cube grain growth with temperature between unpolished $\mathbf{A}$ and $\mathbf{B}$ specimens. 
653 and $673 \mathrm{~K}\left(335,360,380\right.$ and $\left.400^{\circ} \mathrm{C}\right)$. Observations of identical regions using ECC did not show any indication of grain boundary migration in A samples till 673 $\mathrm{K}\left(400^{\circ} \mathrm{C}\right)$ when some preferential grain growth was observed in keeping with discontinuous growth. Thus the annealing characteristics of the starting $\mathbf{A}$ material is consistent with the cold-worked and recrystallized grain growth pattern depicted in Figure 1.

\section{Metallographic Examination}

In Figure 2, the micrographs of the identical area which were relocated by fiducial markers are shown for the sequences; as-rolled, annealed at $523 \mathrm{~K}\left(250^{\circ} \mathrm{C}\right)$ for 40 minutes, and annealed at $543 \mathrm{~K}\left(270^{\circ} \mathrm{C}\right)$ for 20 minutes. The heating programs for all specimens are listed in Table 2 . The banded effect is due to the elongation of original grains parallel to the RD. EBSP examination showed that some of the small grains (Figure $3 \mathrm{a}$ ) less than $5 \mu \mathrm{m}$ were recrystallized whereas the corrugated structure appear to be recovered with undulating orientation about a mean parent (deformed) orientation (Figure $3 b$ ). These structures were found within the different bands in Figure $2 b$ and appear to be highly dependent on the initial orientation of each grain. However, in A samples these recrystallization resistant grains were in the minority. An initial fast recrystallization stage with grain sizes below $10 \mu \mathrm{m}$ was recently noted by Furu and



Figure 2a ECC micrograph of electropolished sample A6 before heat treatment. 


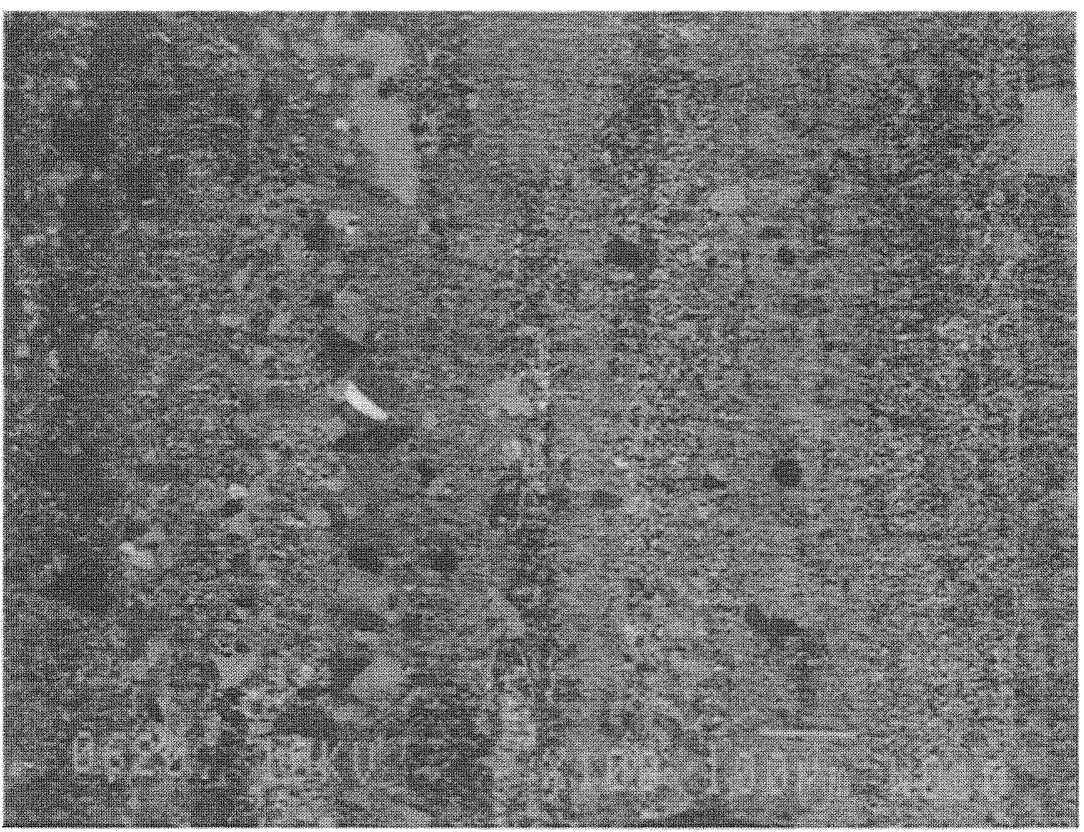

Figure 2b Identical area as shown in Figure $2 \mathrm{a}$ after heat treated at $250^{\circ} \mathrm{C}$ for 40 minutes.

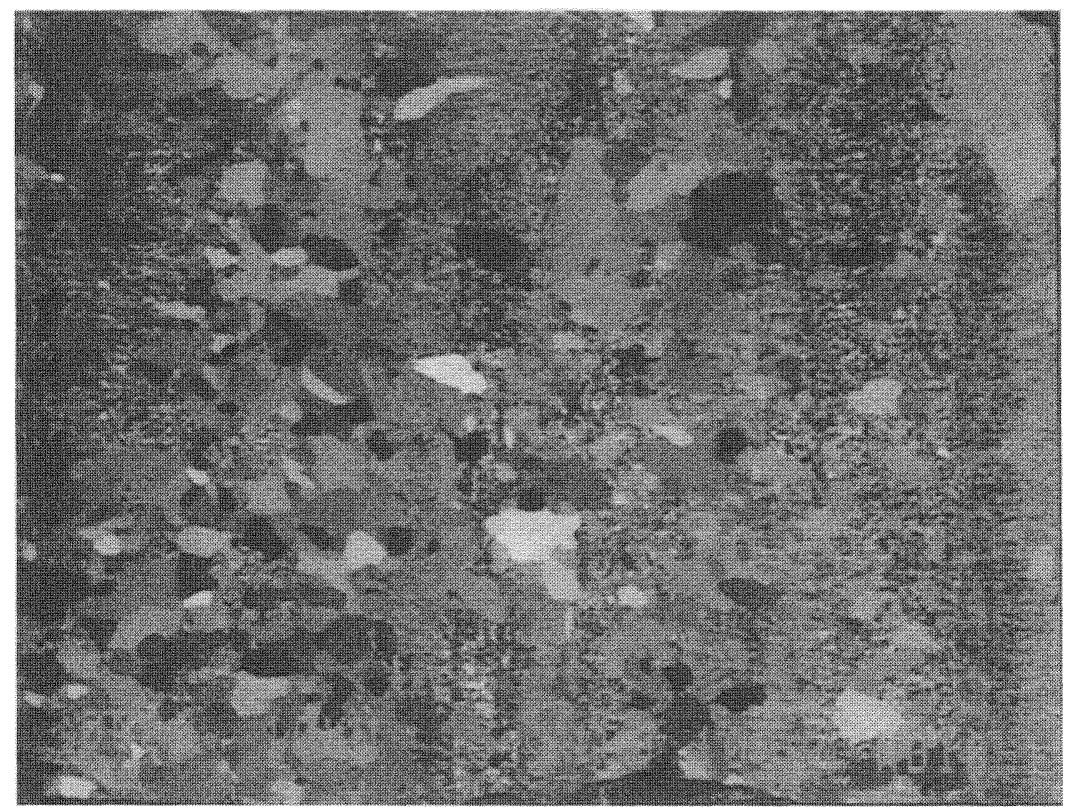

Figure 2c Identical area after further treated at $270^{\circ} \mathrm{C}$ for 20 minutes. 


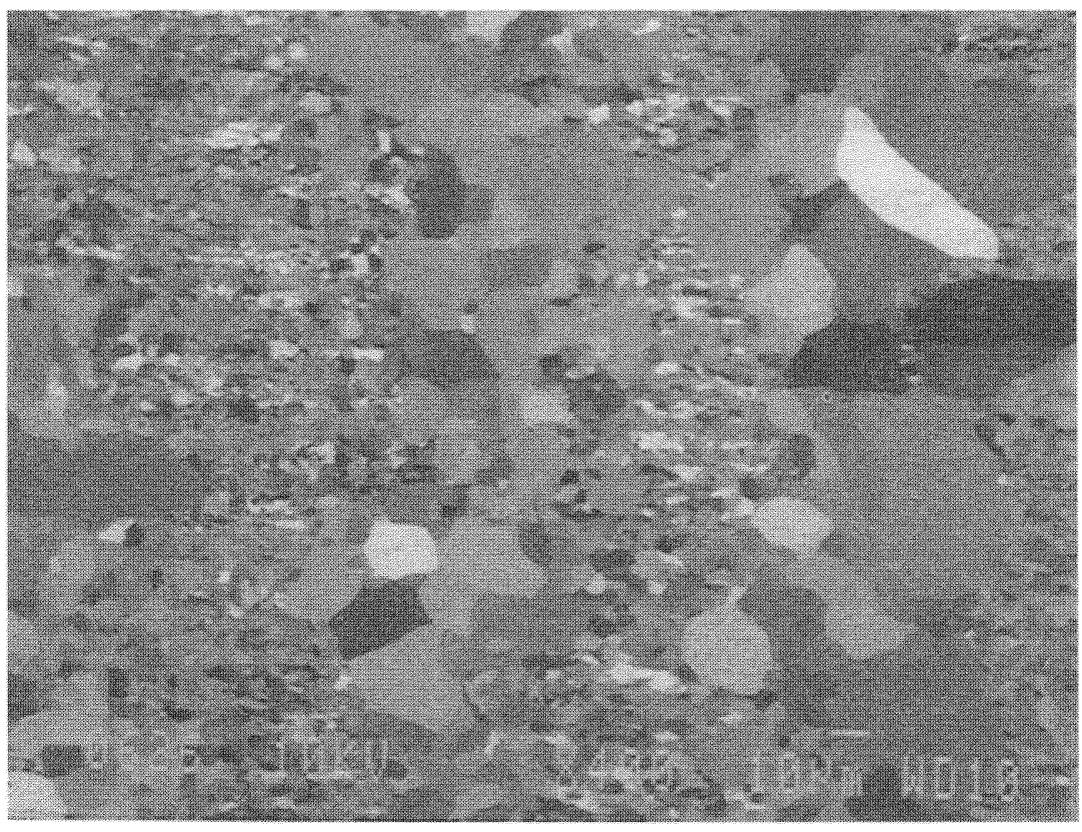

Figure 3a Small recrystallized grains in $\mathrm{A} 6$ at $250^{\circ} \mathrm{C}$ for 40 minutes.

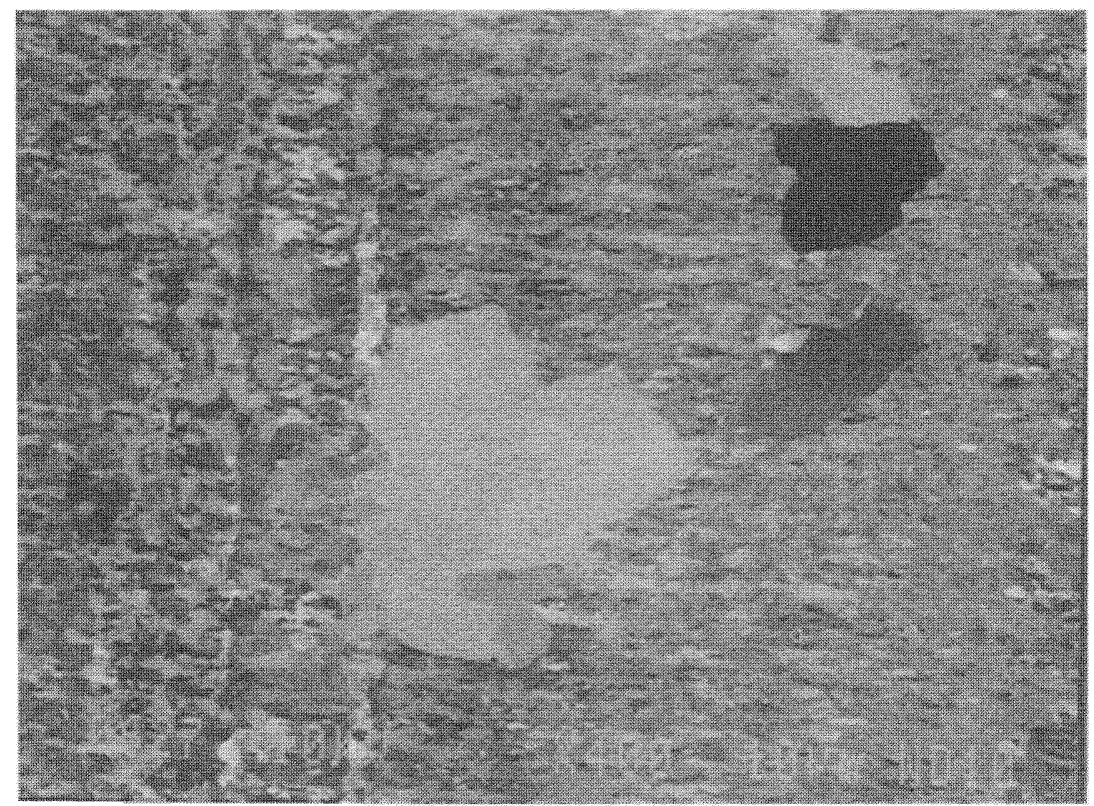

Figure 3b Recovered (deformed) structure of $\mathrm{A} 6$ annealed at $250^{\circ} \mathrm{C}$ for 40 minutes. 
Nes (1993). Annealing a different A specimen at $563 \mathrm{~K}\left(290^{\circ} \mathrm{C}\right)$ for 20 minutes (Figure 4) shows almost complete recrystallization with the largest grains not more than twice of that after anneals at $543 \mathrm{~K}\left(270^{\circ} \mathrm{C}\right)$ (Figure $2 \mathrm{c}$ ). Thus the characteristics of recrystallization of the $A$ samples appears to be:

i) numerous recrystallization sites within each grain, the growth of which is retarded by fine particle distribution.

ii) although quantitative statistical analysis has not been completed, the grain growth observed in the $523 \mathrm{~K}\left(250^{\circ} \mathrm{C}\right)$ to $563 \mathrm{~K}\left(290^{\circ} \mathrm{C}\right)$ range is primarily driven by larger grains devouring finer ones which formed during the initial fast recrystallization stage, that is the driving force is grain boundary energy.

On the other hand, the B samples after 40 minutes at $533 \mathrm{~K}\left(260^{\circ} \mathrm{C}\right)$ (Figure $5 \mathrm{a}$ ) show very little recrystallization, but recrystallization is almost complete after 40 minutes at $568 \mathrm{~K}\left(295^{\circ} \mathrm{C}\right)$ (Figure $\left.5 \mathrm{~b}\right)$. A different B specimen showed that the growing grains, which originate near the grain boundary of the prestrained structure is much larger during the partially recrystallized stage and the corrugated structure is much more prevalent than in A samples. Moreover in Figure 6, from an adjoining area in Figure 5b, EBSP analysis shows that even these remnant portions retain the recovered structure rather than a fine grain recrystallized one. Thus the characteristics of recrystallization of the B sample appear to be:



Figure $4 \mathrm{ECC}$ micrograph of $\mathrm{A} 3$ annealed at $290^{\circ} \mathrm{C}$ for 20 minutes showing near complete recrystallization. 


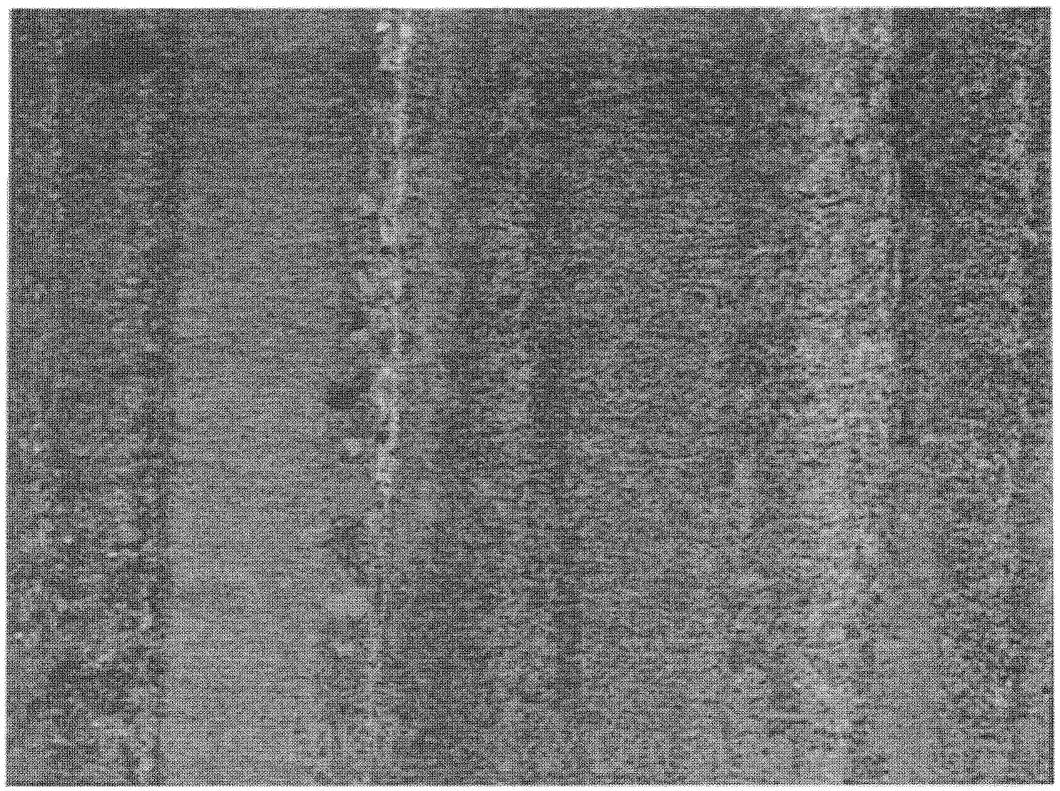

Figure 5a Recovered structure of sample B after heat treated at $260^{\circ} \mathrm{C}$ for 40 minutes.

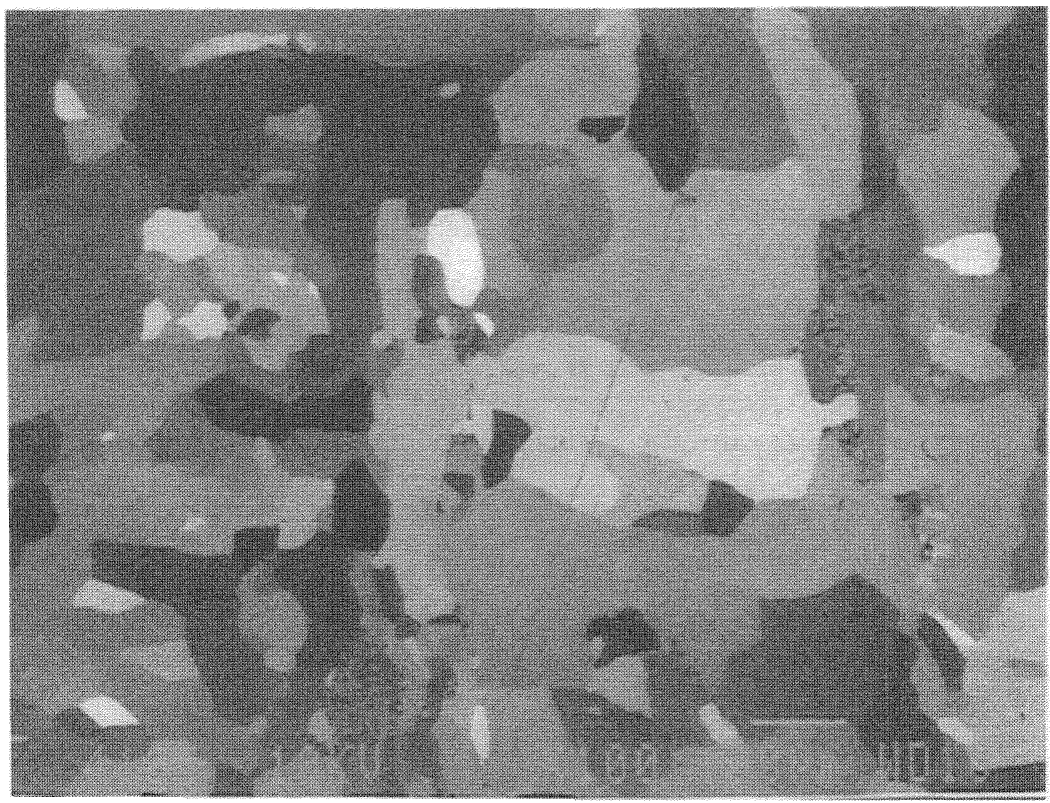

Figure 5b Nearly complete recrystallization of sample B after heat treated at $295^{\circ} \mathrm{C}$ for 40 minutes. 


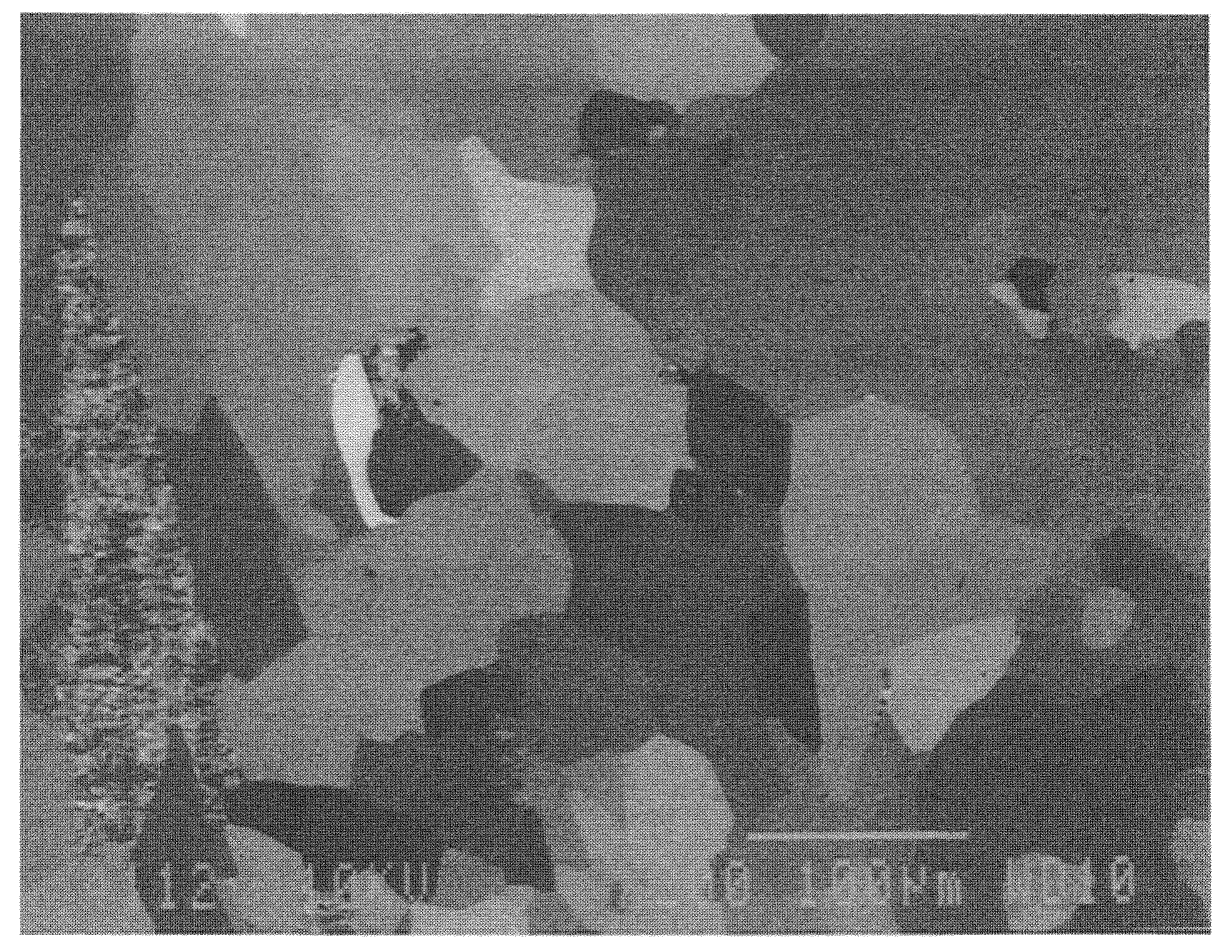

Figure 6 Retained deformed structure in sample B after heat treated at $295^{\circ} \mathrm{C}$ for 40 minutes.

i) preferential nucleation around prior grain boundaries.

ii) grain growth in the 533 to $568 \mathrm{~K}\left(260\right.$ to $\left.295^{\circ} \mathrm{C}\right)$ range occurs by transforming the recovered (deformed) grains, that is the driving force is stored work in the recovered original grains.

The above clearly indicates that the purer A matrix undergoes continuous recrystallization whereas the less pure $\mathbf{B}$ one undergoes discontinuous recrystallization. Evidence for continuous recrystallization in $99.996 \% \mathrm{Al}$ was also found by Rosen et al. (1993) after cold rolling to $50 \%$ reduction and annealing at 473 and $523 \mathrm{~K}\left(200^{\circ} \mathrm{C}\right.$ and $\left.250^{\circ} \mathrm{C}\right)$.

\section{ODF Analysis}

For the sake of space conservation, ODF diagrams are not presented, but the analytical results are presented in the form of volume fractions of texture components as described by Hirsch and Luicke (1985) and listed in Table 2 using a Gaussian spread angle, $\psi$, of $11^{\circ}$. The remarkable feature of the as-rolled texture (near the surface) in both $\mathbf{A}$ and $\mathbf{B}$ samples is that the copper texture, $\mathrm{Cu}_{1}$ and $\mathrm{Cu}_{2}$, components are very low compared to the deformed texture $\left.S_{2}\{123\}<634\right\rangle$, and the brass, Bs. On the other hand, Hirsch and Lücke (1985) found that the volume fraction of texture components 
Table 2 Calculated ODF volume fractions and the corresponding heat treatment schedules*.

\begin{tabular}{|c|c|c|c|c|c|c|c|}
\hline$\psi=11^{\circ}$ & Cube & Goss & Brass & $S_{I}$ & $S_{2}$ & $C u_{1}$ & $\mathrm{Cu}_{2}$ \\
\hline $\begin{array}{l}\text { A4 } \\
\text { As Received } \\
\text { HT }-270^{\circ} \mathrm{C} \\
\text { HT }-320^{\circ} \mathrm{C} \\
\text { HT }-380^{\circ} \mathrm{C}\end{array}$ & $\begin{array}{r}0.26 \\
1.23 \\
10.87 \\
18.42\end{array}$ & $\begin{array}{l}0.28 \\
0.27 \\
0.26 \\
0.25\end{array}$ & $\begin{array}{r}19.63 \\
22.24 \\
4.11 \\
2.57\end{array}$ & $\begin{array}{l}1.74 \\
1.68 \\
1.35 \\
1.36\end{array}$ & $\begin{array}{l}49.05 \\
35.52 \\
12.01 \\
10.07\end{array}$ & $\begin{array}{l}2.12 \\
1.42 \\
2.30 \\
1.69\end{array}$ & $\begin{array}{l}1.20 \\
1.20 \\
0.76 \\
0.93\end{array}$ \\
\hline $\begin{array}{l}\text { A6 } \\
\text { As Received } \\
\text { HT }-250^{\circ} \mathrm{C} \\
\text { HT }-270^{\circ} \mathrm{C} \\
\text { HT }-390^{\circ} \mathrm{C} \\
\text { HT }-420^{\circ} \mathrm{C}\end{array}$ & $\begin{array}{r}0.51 \\
0.52 \\
1.19 \\
19.52 \\
25.71\end{array}$ & $\begin{array}{l}0.28 \\
0.26 \\
0.24 \\
0.50 \\
0.41\end{array}$ & $\begin{array}{r}26.37 \\
28.45 \\
25.96 \\
2.53 \\
2.42\end{array}$ & $\begin{array}{l}2.01 \\
2.18 \\
2.13 \\
1.43 \\
1.96\end{array}$ & $\begin{array}{l}20.57 \\
20.21 \\
18.82 \\
12.79 \\
12.05\end{array}$ & $\begin{array}{l}2.17 \\
1.72 \\
1.64 \\
1.67 \\
1.60\end{array}$ & $\begin{array}{l}0.71 \\
0.82 \\
0.82 \\
0.53 \\
0.90\end{array}$ \\
\hline $\begin{array}{l}A 3 \\
\text { HT }-280^{\circ} \mathrm{C} \\
\text { HT }-290^{\circ} \mathrm{C}\end{array}$ & $\begin{array}{l}2.70 \\
9.80\end{array}$ & $\begin{array}{l}0.57 \\
0.26\end{array}$ & $\begin{array}{l}20.80 \\
11.22\end{array}$ & $\begin{array}{l}3.19 \\
1.70\end{array}$ & $\begin{array}{l}33.97 \\
19.11\end{array}$ & $\begin{array}{l}1.45 \\
2.07\end{array}$ & $\begin{array}{l}1.11 \\
0.72\end{array}$ \\
\hline $\begin{array}{l}B 4 \\
\text { As Received } \\
\text { HT }-260^{\circ} \mathrm{C} \\
\text { HT } 295^{\circ} \mathrm{C} \\
\text { HT }-320^{\circ} \mathrm{C}\end{array}$ & $\begin{array}{l}0.32 \\
0.47 \\
5.64 \\
7.85\end{array}$ & $\begin{array}{l}2.03 \\
0.24 \\
0.21 \\
0.07\end{array}$ & $\begin{array}{r}39.38 \\
37.12 \\
8.24 \\
6.49\end{array}$ & $\begin{array}{l}1.50 \\
1.65 \\
1.43 \\
1.93\end{array}$ & $\begin{array}{l}34.17 \\
30.50 \\
15.16 \\
15.39\end{array}$ & $\begin{array}{l}0.67 \\
0.78 \\
1.16 \\
1.09\end{array}$ & $\begin{array}{l}0.72 \\
0.53 \\
0.82 \\
0.91\end{array}$ \\
\hline
\end{tabular}

*Thermal Histories:

A4:

HT-270: $3^{\circ} \mathrm{C} / \mathrm{min}$ to $250^{\circ} \mathrm{C}(20 \mathrm{~min})$, then $20^{\circ} \mathrm{C} / \mathrm{min}$ to $260^{\circ} \mathrm{C}(20 \mathrm{~min}), 20^{\circ} \mathrm{C} / \mathrm{min} 270^{\circ} \mathrm{C}(20 \mathrm{~min})$. HT-320: $20^{\circ} \mathrm{C} / \mathrm{min}$ to $270^{\circ} \mathrm{C}(10 \mathrm{~min}), 280^{\circ} \mathrm{C}(10 \mathrm{~min}), 290^{\circ} \mathrm{C}(10 \mathrm{~min}), 300^{\circ} \mathrm{C}(10 \mathrm{~min}), 320^{\circ} \mathrm{C}$ (10 $\mathrm{min})$.

HT-380: $20^{\circ} \mathrm{C} / \mathrm{min}$ to $310^{\circ} \mathrm{C}(10 \mathrm{~min}), 320^{\circ} \mathrm{C}(10 \mathrm{~min}), 340^{\circ} \mathrm{C}(10 \mathrm{~min}), 360^{\circ} \mathrm{C}(10 \mathrm{~min})$ and $380^{\circ} \mathrm{C}$ (20 $\mathrm{min})$.

A6:

HT-250: $3^{\circ} \mathrm{C} / \mathrm{min}$ to $250^{\circ} \mathrm{C}(40 \mathrm{~min})$

HT-270: $20^{\circ} \mathrm{C} / \mathrm{min}$ to $250^{\circ} \mathrm{C}(20 \mathrm{~min}), 20^{\circ} \mathrm{C} / \mathrm{min} 260^{\circ} \mathrm{C}(20 \mathrm{~min}), 20^{\circ} \mathrm{C} / \mathrm{min}$ to $270^{\circ} \mathrm{C}(20 \mathrm{~min})$.

HT-390: $20^{\circ} \mathrm{C} / \mathrm{min}$ to $270^{\circ} \mathrm{C}(20 \mathrm{~min}), 3^{\circ} \mathrm{C} / \mathrm{min}$ to $370^{\circ} \mathrm{C}(10 \mathrm{~min}), 380^{\circ} \mathrm{C}(10 \mathrm{~min}), 20^{\circ} \mathrm{C} / \mathrm{min}$ to $385^{\circ} \mathrm{C}(10 \mathrm{~min}), 390^{\circ} \mathrm{C}(10 \mathrm{~min})$.

HT $-420: 20^{\circ} \mathrm{C} / \mathrm{min}$ to $380^{\circ} \mathrm{C}(10 \mathrm{~min}), 390^{\circ} \mathrm{C}(10 \mathrm{~min}), 400^{\circ} \mathrm{C}(20 \mathrm{~min}), 410^{\circ} \mathrm{C}(20 \mathrm{~min})$ and $420^{\circ} \mathrm{C}$ (20 $\mathrm{min})$.

A3:

HT-280: $20^{\circ} \mathrm{C} / \mathrm{min}$ to $280^{\circ} \mathrm{C}(10 \mathrm{~min})$.

HT-290: $20^{\circ} \mathrm{C} / \mathrm{min}$ to $280^{\circ} \mathrm{C}(10 \mathrm{~min}), 290^{\circ} \mathrm{C}(10 \mathrm{~min})$.

B4:

HT-260: $3^{\circ} \mathrm{C} / \mathrm{min}$ to $260^{\circ} \mathrm{C}(40 \mathrm{~min})$.

HT-295: $20^{\circ} \mathrm{C} / \mathrm{min}$ to $260^{\circ} \mathrm{C}(10 \mathrm{~min}), 270^{\circ} \mathrm{C}(10 \mathrm{~min}), 280^{\circ} \mathrm{C}(20 \mathrm{~min}), 290^{\circ} \mathrm{C}(20 \mathrm{~min}), 295^{\circ} \mathrm{C}$ $(40 \mathrm{~min})$.

HT-320: $20^{\circ} \mathrm{C} / \mathrm{min}$ to $290^{\circ} \mathrm{C}(10 \mathrm{~min}), 295^{\circ} \mathrm{C}(10 \mathrm{~min}), 305^{\circ} \mathrm{C}(10 \mathrm{~min}), 320^{\circ} \mathrm{C}(10 \mathrm{~min})$.

from mid-plane of pure $\mathrm{Al}$, calculated using orthorhombic symmetry were $\mathrm{S}, \mathrm{Cu}, \mathrm{Bs}$ in decreasing order. This difference may be due to the fact that the present measurements were purposely taken near the surface where the aforementioned asymmetry of deformation increases as the plane of examination moves away from the mid-plane of the sheet. The large divergence in the $S_{1}$ and $S_{2}$ components is attributed to this fact. 
For anneal of $40 \mathrm{~min}$ at $523 \mathrm{~K}\left(250^{\circ} \mathrm{C}\right)$, continuous recrystallization was almost complete and is in agreement with Rosen et al. (1993) but cube texture did not start to grow till $543 \mathrm{~K}\left(270^{\circ} \mathrm{C}\right)$. Similar observations have been made in high purity $\mathrm{Al}$ at lower temperatures (Heller, Slakhorst and Verbraak, 1977).

Figure 7 is a collective plot of volume fraction for the cube texture component of both $\mathbf{A}$ and $\mathbf{B}$ samples. Although this graph is not a true isochronal plot, it depicts the primary recrystallization process and supplements Figure 1. Furthermore, in the recrystallization range of 523 to $563 \mathrm{~K}\left(250\right.$ to $\left.290^{\circ} \mathrm{C}\right)$ for A samples, the Bs component initially increases and then sharply decreases in unison with cube texture growth. Such behaviour has been noted by Hutchison (1974). The $S_{2}$ component, on the other hand,

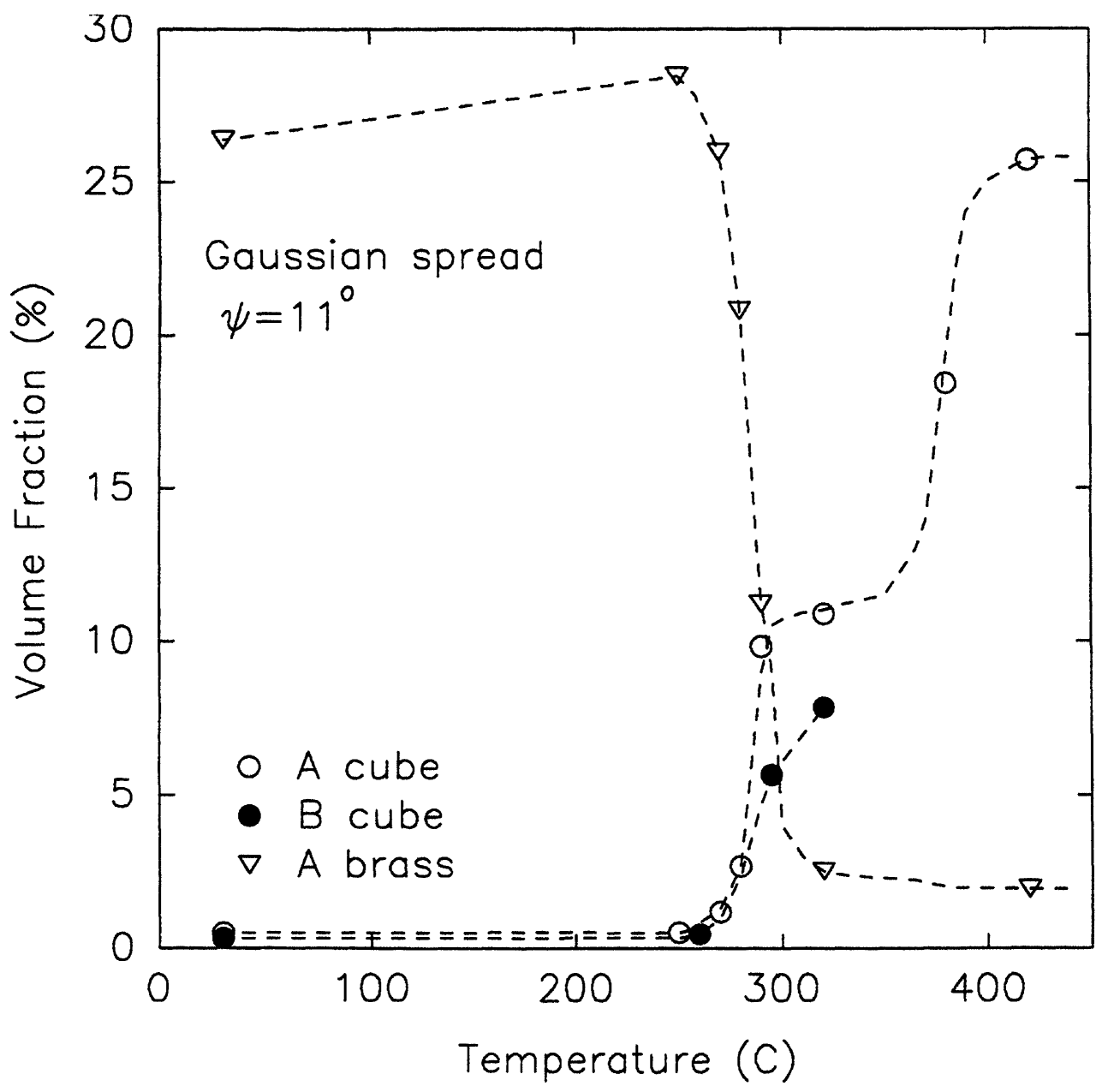

Figure 7 Variation of calculated volume fractions of Cube and Brass components for sample $\mathbf{A}$ and $\mathbf{B}$ as a function of heat treatment given in Table 2 . 
appear to continuously decrease, but a large portion is retained even upon heating to $693 \mathrm{~K}\left(420^{\circ} \mathrm{C}\right)$. If comparison is made between specimens $\mathrm{A} 4$ and $\mathrm{A} 6$ at 653 and 663 $\mathrm{K}\left(380\right.$ and $390^{\circ} \mathrm{C}$ ), respectively (Table 2 ), the cube component does not correlate to the large differences in $S_{2}$. The large amount of $S$ component retained after recrystallization has been discussed by Hirsch and Lücke (1985), but any clarification requires further in-depth study which is beyond the scope of this current study. In contrast, B sample which has higher solute content (Table 1) results in much higher Bs component in the as-rolled condition than the case for $\mathbf{A}$, but the amount of cube texture formation is much less. This is consistent with the general findings that cube texture formation decreases as the amount of $\mathrm{Fe}$ in solution increases (Ito, Musick and Lücke, 1983).

\section{Kinetic Study of Cube Texture Growth}

Figure 8 shows that the intensity changes with temperature using the (111) scans. These scans are taken at two specific positions in the (111) pole figure where the maximum (111) intensity occurred at $\chi^{+}$and $\chi$ - positions with $\phi=0$. The difference in intensities

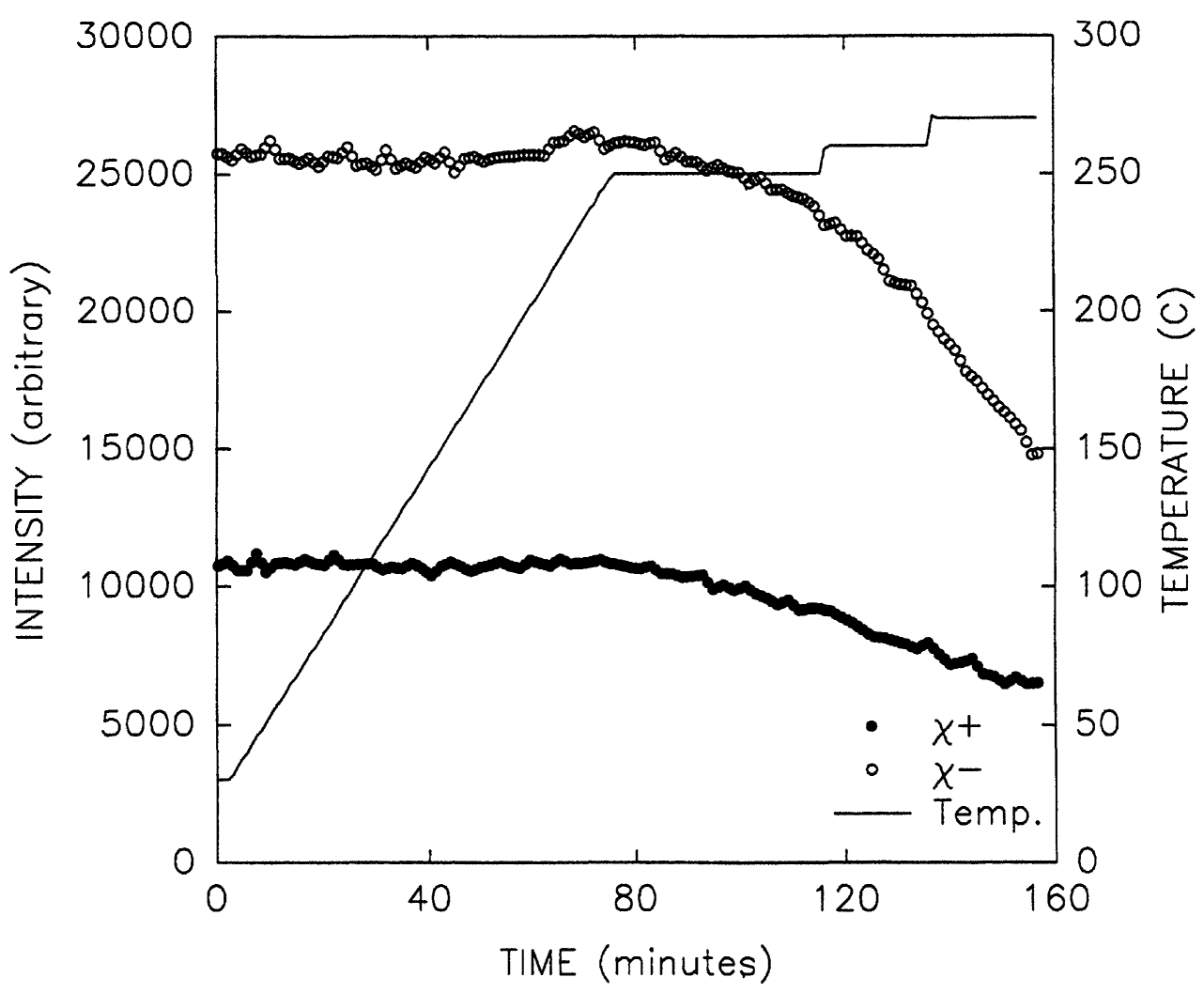

Figure 8 (111) intensity for both maxima positions of $\chi^{+}$and $\chi$ - as a function of time and temperature. 
is evidence of the asymmetry previously noted (Saimoto et al., 1993). It is clearly seen that the intensities do not change very much with increase in temperature at a temperature ramp rate of $3^{\circ}$ minute up to $523 \mathrm{~K}\left(250^{\circ} \mathrm{C}\right)$. However, upon holding at $523 \mathrm{~K}\left(250^{\circ} \mathrm{C}\right)$, the intensity gradually decreases and correlates to the metallographic evidence of incipient recrystallization if an A specimen is held at $523 \mathrm{~K}\left(250^{\circ} \mathrm{C}\right)$ for 40 minutes (Figure $2 \mathrm{~b}$ ). In some cases a measurable increase is observed during the heating range of 398 to $523 \mathrm{~K}\left(125\right.$ to $\left.250^{\circ} \mathrm{C}\right)$, which could correlate to the aforementioned increase in Bs component since the $S_{2}$ monotonically decreases.

Figure 9 shows that the $(200)$ intensity increases during isothermal holding times and that the change of slope occurs upon rapid temperature change of $20 \%$ minute. From such temperature change tests, an apparent activation energy, $\mathrm{Q}$, can be determined. Although there are difficulties experimentally in achieving instantaneous temperature increases, this determination is model independent unlike the conventional method. The value for $\mathbf{A}$ sample is depicted in Figure 9 and is about $1.9 \pm 0.2 \mathrm{eV}(182 \mathrm{~kJ} / \mathrm{mol})$. The large scatter in the data of A sample is attributed to the occurrence of the aforementioned continuous recrystallization resistant deformed grains and to the ambiguity as to whether the $\chi, \Phi$ position are located for only grains which grow.

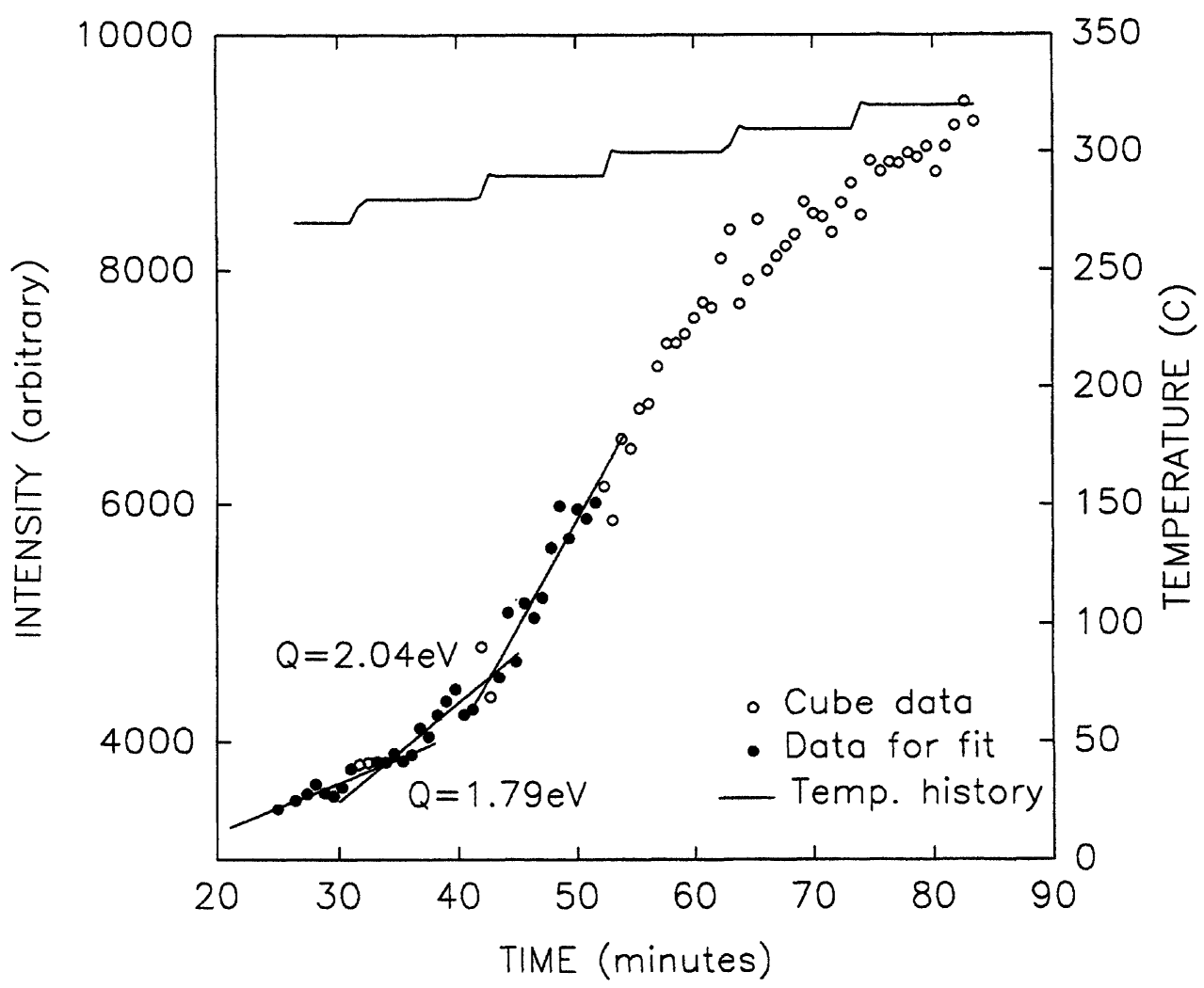

Figure 9 Change in (200) intensity for A4 as a function of designated times and temperatures. 
Thus the $Q$ determinations could vary depending on the selection of data points for the regression analysis. The designated values in the figures used the following criterion. The data points taken during the transition and one after the change were dropped since each scan took about 40 seconds. Thus the true $Q$ value for cube grain growth after the rapid initial recrystallization stage may be lower but above $1.27 \mathrm{eV}(122 \mathrm{~kJ} / \mathrm{mol})$ for self diffusion of $\mathrm{Al}, \mathrm{Q}_{\mathrm{Al}}$ (Hood, 1986). Obviously at temperatures beyond $563 \mathrm{~K}$ $\left(280^{\circ} \mathrm{C}\right)$ the kinetics is being interfered by the particle drag mechanism which retards grain boundary migration as the grain size approaches the critical Zener drag condition as revealed metallographically.

Figure 10 shows a similar plot for a $\mathbf{B}$ sample. The measured $Q$ values are larger than those for A. Since the scatter in the data points are smaller in this series, except for the inserted figure data where the number of counts is small, the measured values near $4.0 \mathrm{eV}(386 \mathrm{~kJ} / \mathrm{mol})$ should be more reliable. Moreover, the observed value is higher than that of $2.46 \mathrm{eV}(237.4 \mathrm{~kJ} / \mathrm{mol})$ (Rummel et al., 1993) for $\mathrm{Fe}$ migration in $\mathrm{Al}$, $\mathrm{Q}_{\mathrm{Fe}-\mathrm{Al}}$. Such high values for random grain boundary migration have been previously reported (Fridman et al., 1973). The plateau in cube texture growth at $568 \mathrm{~K}\left(295^{\circ} \mathrm{C}\right)$ correspond to complete recrystallization suggesting that grain impingement has suddenly

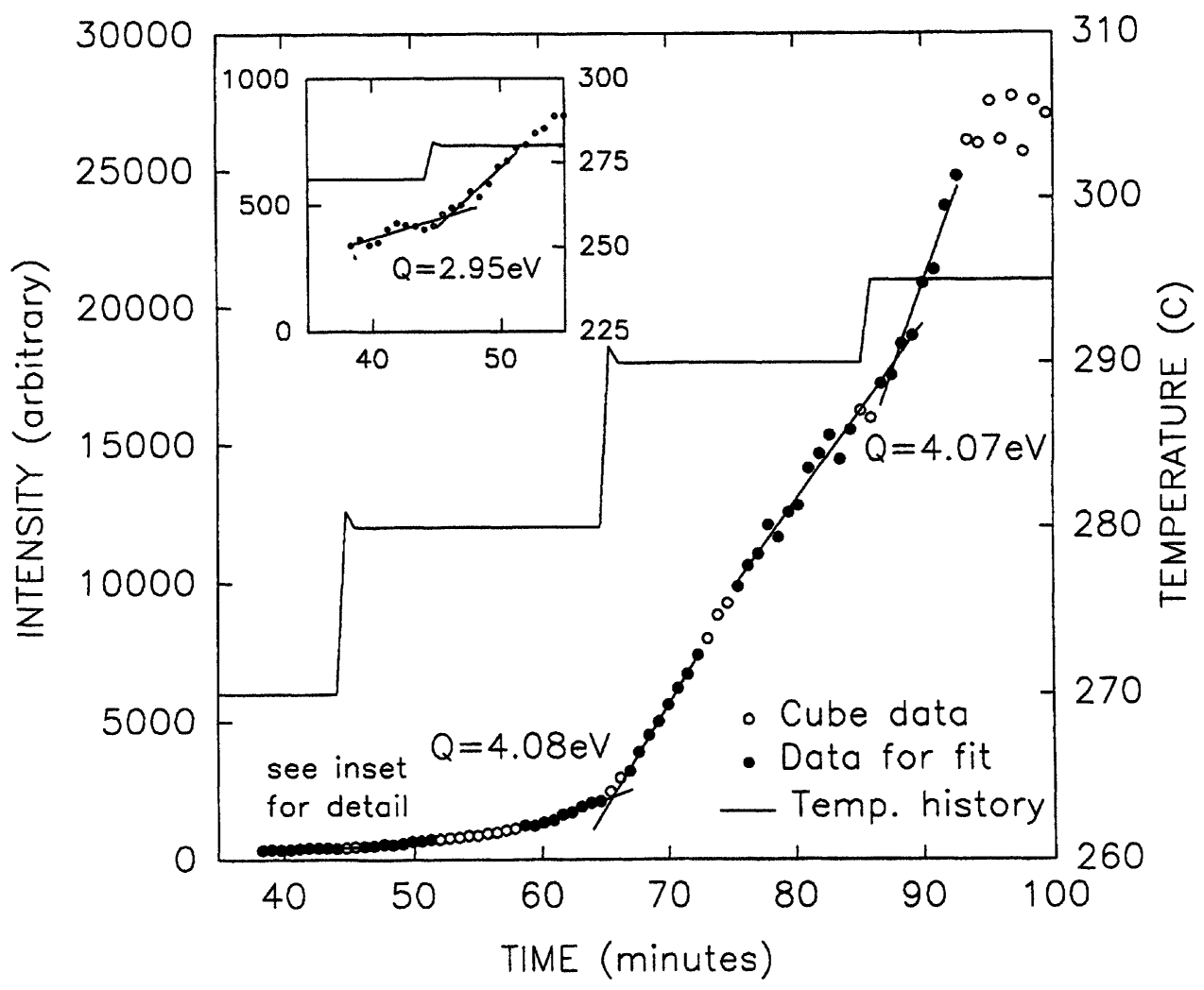

Figure 10 Change in (200) intensity for B4 as a function of designated times and temperatures. 
reduced the growth rate. This is in keeping with the discontinuous recrystallization phenomenon.

The isothermal portion of specimen B4 at $563 \mathrm{~K}\left(290^{\circ} \mathrm{C}\right)$ (Figure 10) suggests a slow monotonic decrease in slope. Although further systematic study is required for validation, it may be that this curvature is indicative of a growth rate which varies inversely with time (Humphreys and Hatherly, 1995).

\section{DISCUSSION}

The results listed in Table 1 and 2 can be summarized as follows:

i) Primary recrystallization in the purer $\mathbf{A}$ sample occurs by continuous recrystallization whereas in the less pure $\mathbf{B}$ one, by discontinuous recrystallization.

ii) Although the volume fraction of $\mathrm{Al}_{3} \mathrm{Fe}$ is only $25 \%$ larger for $\mathbf{A}$ versus $\mathbf{B}$, the grain refinement in $\mathbf{A}$ is more than twice as effective indicating that the particle sizes in these cases are very different.

iii) Cube texture development under continuous recrystallization conditions is more effective than under the discontinuous case.

iv) The apparent activation energy for the purer matrix $\mathbf{A}$ is above that for $\mathrm{Al}$ self diffusion but less than that for $\mathrm{Fe}$ in Al. For B matrix, the apparent activation energy is higher than that for $\mathrm{Fe}$ in $\mathrm{Al}$.

Detailed EBSP examination of specific grains before and after heat treatment and limited population counts of cube grains in partially recrystallized microstructure are consistent with the above gross metallographic and textural analysis. However, such studies are more cost effective for large grain growth above $608 \mathrm{~K}\left(335^{\circ} \mathrm{C}\right)$ which will be reported later. For the present discussion, we will focus on the difference between the apparent activation energies and on the possible mechanistic reasons.

Earlier work by Gordon and El-Bassyouni (1965) suggests that $\mathrm{Fe}$ is the most important element in affecting grain growth. Thus present dramatic difference must be due to this precipitation of $\mathrm{Fe}$ during 10 hours anneal at $608 \mathrm{~K}\left(335^{\circ} \mathrm{C}\right)$ versus $1 \mathrm{hr}$ at $673 \mathrm{~K}\left(400^{\circ} \mathrm{C}\right)$. The measured $\mathrm{Fe}$ impurity levels in the matrix stabilized at the above temperatures are $0.83 \mathrm{ppm}$ for $\mathbf{A}$ and $2.26 \mathrm{ppm}$ for $\mathbf{B}$.

Fridman et al. (1975) who investigated the motion of $\langle 100\rangle$ tilt boundaries in $\mathrm{Al}$ bicrystals reported that the migration activation energy for the random high angle boundaries increases dramatically from $0.7 \mathrm{eV}(67 \mathrm{~kJ} / \mathrm{mol})$ to a maximum of $2.8 \mathrm{eV}$ (269 $\mathrm{kJ} / \mathrm{mol}$ ) in the total solute range of 2 to $20 \mathrm{ppm}$ (atomic). Unfortunately the $\mathrm{Fe}$ composition was not separated from the other elements, but it ranged from 0.5 to 5 ppm. Remarkably the matrix compositions of $\mathbf{A}$ and $\mathbf{B}$ samples reside within this range. Although their experiments were carried out at 667, 769 and $909 \mathrm{~K}$ (394, 496 and $636^{\circ} \mathrm{C}$ ) considerably higher than in the current studies, their argument that the increasing activation energy values are due to adsorption of foreign atoms at the mismatch positions in the interface appears reasonable.

As shown by Lücke and Stüwe (1971) earlier, the apparent activation energy for the migration of grain boundaries with adsorbed foreign atoms can be expressed as $\mathrm{Q}=\mathrm{Q}_{\text {solute }}+\mathrm{U}_{\mathrm{o}}-2 \mathrm{kT}$, where $\mathrm{Q}_{\text {solute }}=\mathrm{Q}_{\mathrm{Fe}-\mathrm{Al}}$ in the present discussion and $\mathrm{U}_{\mathrm{o}}$ is binding energy between grain boundary and the solute. This derivation assumes that as the grain boundary moves the segregated solutes which become displaced from the moving 
interface will resegregate and this action will cause a drag force on the moving boundary. The refinement by Fridman et al. (1975) is to quantitatively incorporate the effect of the degree of segregation.

For the present purpose it can be concluded that the B sample must have complete segregation since it was thermally stabilized at $673 \mathrm{~K}\left(400^{\circ} \mathrm{C}\right)$ and the matrix is supersaturated at the recrystallization temperature. Thus the maximum estimated $U_{0}=$ $\mathrm{Q}-2.47+0.1=1.6 \mathrm{eV}(155.4 \mathrm{~kJ} / \mathrm{mol})$. A value of $0.78 \mathrm{eV}(75 \mathrm{~kJ} / \mathrm{mol})$ was estimated by Fridman et al. (1975) using the total composition of $10 \mathrm{ppm}$ rather than just the $\mathrm{Fe}$ content. However $\mathrm{Fe}$ is a transition element which gives rise to a large $\mathrm{Q}_{\mathrm{Fe}-\mathrm{Al}} / \mathrm{Q}_{\mathrm{Al}}$ ratio. Since the effect of $\mathrm{Fe}$ solute on the recrystallization temperature is so large (Humphreys and Hatherly, 1995), the present finding of a large binding energy should not be surprising.

On the other hand, the A sample manifested apparent activation energies lower than that for $\mathrm{Q}_{\mathrm{Fe}-\mathrm{Al}}$. In the model of Fridman et al. (1975), for an incompletely segregated grain boundary, the interface may not be plane but has many protrusions with ledge structure. This geometry may permit the solute atoms which give rise to boundary drag to migrate by grain boundary diffusion as well as bulk diffusion which will lower the measured $Q$ values as observed. Thus qualitatively the present results can be interpreted by the grain boundary segregation and drag model.

The present results are complicated since the observed discontinuous recrystallization must be due to the stabilizing effect of $\mathrm{Fe}$ in solution. Previous study (Legace and Saimoto, 1986) of $\mathrm{Cr}$ in $\mathrm{Al}$ has shown that transition elements do heterogeneously segregate to dislocations and coherently precipitate. Since the degree of segregation in the current study seems to be very sensitive in the 1 to $2 \mathrm{ppm}$ of Fe range, the heating rate and intermediate anneals should greatly affect recrystallization. This precipitation during recrystallization have been confirmed by resistivity measurements (Ito, Musick and Lücke, 1983), but its effect on the kinetics has not been investigated. To improve design of experiments or processing, a more precise $\mathrm{Fe}-\mathrm{Al}$ phase diagram at low temperatures than currently available (Ito, Musick and Lücke, 1983), is necessary and will be discussed elsewhere (Diak and Saimoto). Another question which arises is the role of the preexisting precipitates due to the initial thermal stabilization treatment. These incoherent particles which become attached to the grain boundary can coarsen and act as sinks for the solute. Thus the change in particle size distribution before and after recrystallization may be measurable. Furthermore the boundary drag mechanism may be validated if the solute composition profile behind the moving boundary can be measured; Fe in Al presents an optimum system for such study. To carry out such experiments, the preparation of ideal specimens is necessary. This study has delineated the thermal mechanical processing history which could result in such specimens for observation in the high resolution transmission electron microscope.

\section{CONCLUSIONS}

The role of thermal-mechanical processing history on continuous and discontinuous recrystallization of nominally pure $\mathrm{Al}$ has been illustrated. The observable microstructural differences can be correlated to the kinetic data but the difference in the driving forces cannot be quantitatively measured. The mobility of the grain boundaries are highly dependent on the matrix solute composition which in turn affects the recovery of the stored energy. Thus subsequent studies on recrystallization should 
ascertain the solute composition directly or indirectly as was the case in this study. The apparent activation energy is highly variable due to the scatter in data due to the inherent nature of the deformed microstructure. Nevertheless, the activation energy for continuous recrystallization is below that of $\mathrm{Fe}$ diffusion in $\mathrm{Al}$ whereas that of discontinuous recrystallization is above it. Hence in the latter case segregated solutes near the moving grain interface must cause a drag indicating that a large binding energy exists between $\mathrm{Fe}$ solutes and the grain boundary.

\section{Acknowledgement}

The authors are grateful to the Light Metals Educational Foundation of Japan and the Natural Sciences and Engineering Research Council (Canada) for generous financial support. We thank Mr. J. Clarke for experimental assistance during the initial stage of this study.

\section{References}

Clarke, A.P., Saimoto, S. and Ho, P. (1994). in Proc. 2nd Intern. Workshop on Stress Induced Phenomenon in Metallization, AIP Proc. 305 eds. P.S. Ho, C-Y. Li and P. Totta, 126-136.

Clarke, A.P. and Saimoto, S. (1995). in W.B. Pearson International Symposium on the Impact of Structures on Material Science, ed. H.W. King, in press.

Cullity, B.D. (1978). Elements of X-ray Diffraction, 2nd ed., Addison-Wesley.

Diak, B.J., Whitehead, M. and Saimoto, S. (1994). in Experimental Methods of Phase Diagram Determination, eds. J.E. Morral, R.S. Schiffman and S.M. Merchant, TMS, 73-81.

Diak, B.J. and Saimoto, S. to be published.

Fridman, E.M., Kopegkii, T.W., Shvindlerman, L.S. and Avistor, V.J. (1973). Z. Metallk., 64, $458-463$.

Fridman, E.M., Kopezky, C.V. and Shvindlerman, L.S. (1975). Z. Metallk., 66, 533-539.

Furu, T. and Nes, E. (1993). Material Science Forum, 113-115, 311-316.

Gordon, $\mathrm{P}$ and El-Bassyouni, T.A. (1965). Trans. AIME. 233, 391-397.

Heller, H., Slakhorst, J. and Verbraak, T. (1977). Z. Metallk., 68, 31-37.

Hirsch, J. and Lücke, K. (1985). Acta metall., 33, 1927-1938.

Hood, G. (1986). in Solute Defect Interaction; Experiment and Theory, eds. Saimoto, S., Purdy, G.R. and Kidson, G. V., Pergamon Press, 83-90.

$\mathrm{Hu}$, Hsun, Sperry, P.R. and Beck, P.A. (1952). Trans. AIME, 194, 76-81.

Hu, Hsu., (1968). in Textures in Research and Practice, eds. J. Grewen and G. Wasserman, 206-226.

Humphreys, F.J., and Hatherly, M. (1995). Recrystallization and Related Annealing Phenomena, Galliard (printers) Ltd.

Hutchinson, W.B. (1974). Metal Science, 8, 185-196.

Ito, K., Musick, R. and Lücke, K. (1983). Acta metall., 31, 2137-2149.

Legace, H. and Saimoto, S. (1986). in Annealing Process-Recovery, Recrystallization and Grain Growth, eds. Hansen, H., et al., Riso, Denmark, 415-420.

Li, Jian, Saimoto, S. and Sang, H. (1994). Material Science Forum, 157-162, 795-800.

Lücke, K., and Stüwe, H.P. (1971). Acta metall., 19, 1087-1099.

Olefjord, I. and Karlson, A. (1986). in Aluminum Technology '86, ed. T. Sheppard, Institute of Metals. 383-391.

Rosen, G.I., Jensen, D.J. and Hansen, N. (1993). Material Science Forum, 113-115, 201-206.

Rummel, G., Zumkley, T. Erdélyi, G., Freitag, K., Hood, G.M. and Mehrer, H. (1993). Defect and Diffusion Forum, 95-98, 715-722.

Saimoto, S. (1986). in Physical Simulation of Welding, Hot Forming and Continuous Casting, CANMET MTL 92-43(TR), ed. Bowker, J.T., III-46-55.

Saimoto, S. Kamat, R.G., Clarke, P. and Van Houtte, P. (1993). Textures and Microstructures, 21 109-120.

Woldt, E. and Juul-Jensen, D. (1995). Metall. Mater. Trans., 26A, 1717-1724. 